В. І. Перцов, О. А. Льовкін, Я. В. Тєлушко Запорізький державний медичний університет

\title{
ВИКОРИСТАННЯ СИМУЛЯЦІЙНИХ ТЕХНОЛОГІЙ ПРИ НАВЧАННІ СТУДЕНТІВ НАДАННЯ ЕКСТРЕНОЇ МЕДИЧНОЇ ДОПОМОГИ
}

\author{
V. I. Pertsov, O. A. Lyovkin, Ya. V. Telushko \\ Zaporizhzhia State Medical University \\ THE USE OF SIMULATION TECHNOLOGY IN STUDY OF STUDENTS ON \\ EMERGENCY MEDICAL CARE PROVIDING
}

\begin{abstract}
Мета дослідження - показати нові ефективні методи навчання студентів, які впроваджені на кафедрі медицини катастроф, військової медицини, анестезіології та інтенсивної терапії Запорізького державного медичного університету.

Матеріали та методи дослідження. Головні ознаки симуляційного навчання: можливість використання манекенів або статистів для повноти та реалістичності моделювання об’єкта в певній ситуації; відпрацювання конкретних практичних навичок з використанням сучасної апаратури без завдання шкоди здоров’ю людини; відпрацювання командної роботи в імітованій конкретній ситуації.

Результати й обговорення. Результатом впровадження стали доведені до автоматизму алгоритми проведення серцеволегеневої реанімації; надання допомоги при політравмі, нефатальному втопленні; питання первинного медичного сортування.

Висновки. 1. Форми симуляційного навчання (командні заняття, майстер-класи, семінари-тренінги, змагання) є високоефективною системою практичної підготовки студентів медичних вузів. 2. Командні заняття є пріоритетною формою відпрацювання алгоритму серцево-легеневої реанімації, надання екстреної медичної допомоги при травмі. 3. Майстер-класи слід використовувати як елемент практичної підготовки під час проведення науково-практичних конференцій. 4. Семінари-тренінги є оптимальною формою навчання у роботі з немедичною аудиторією (військовослужбовцями, волонтерами, школярами). 5. Змагання допомагають студентам вдосконалити практичні навички, оволодіти навичками первинного медичного сортування тощо.
\end{abstract}

Ключові слова: симуляційне навчання; студенти медичного університету; екстрена медична допомога.

The aim of the study - to show new effective methods of teaching students that are embedded in the Department of Disaster Medicine, Military Medicine, Anesthesiology and Intensive Care of Zaporizhzhia State Medical University.

Materials and Methods. The main features of simulation training is the use of dummies or extras to complete and realistic simulation of an object in a particular situation; working out specific practical skills using modern equipment without damage to human health; practicing teamwork in the imitated situation.

Results and Discussion. The introduction were driven to automatism algorithms of cardiopulmonary resuscitation; trauma management, drowning; initial triage issues.

Conclusions. 1. Forms simulation training system is highly practical training of medical students. 2. Team classes have priority form working algorithm cardiopulmonary resuscitation, trauma management. 3. Master classes should be used as a part of practical training during scientific conferences. 4. Training seminars are the best form of training in working with non-medical audience (military personnel, volunteers, students). 5. Competitions help students to improve practical skills, develop the skills of primary triage and more.

Key words: simulation training; students of medical university; emergency medical care.

Вступ. Високий темп розвитку науково-технічного прогресу в медицині (поява сучасної апаратури та нових технологій при наданні екстреної медичної допомоги (ЕМД)) змінив вимоги до професійного рівня лікарів. Система навчання висуває на перший план проблему вдосконалення медичної освіти. Актуальним залишається підвищення якості володіння практичними навичками під час надання ЕМД [1-4]. На жаль, “класичні” форми навчання (лекції, семінари, обговорення ситуації біля ліжка хворого та інші) не формують у тих, хто навчається, (с) В. І. Перцов, О. А. Льовкін, Я. В. Тєлушко абсолютно стійкого алгоритму дій. Це призводить до того, що в критичній ситуації лікарю важко швидко мобілізуватися, автоматично та якісно надати ЕМД постраждалому [1, 2].

Мета дослідження - показати нові ефективні методи навчання студентів, які впроваджені на кафедрі медицини катастроф, військової медицини, анестезіології та інтенсивної терапії Запорізького державного медичного університету (ЗДМУ).

Матеріали та методи дослідження. 3 нашої точки зору, симуляційне навчання $(\mathrm{CH})$, за яким навчають у спеціальному штучно створеному імітованому се- 
редовищі, є найбільш прийнятним. Головні ознаки $\mathrm{CH}$ - це можливість використання манекенів або статистів для повноти та реалістичності моделювання об’єкта в певній ситуації; відпрацювання конкретних практичних навичок з використанням сучасної апаратури без завдання шкоди здоров’ю людини; відпрацювання командної роботи в імітованій конкретній ситуації [2, 3]. ЗДМУ має всі можливості для вирішення такого завдання.

Результати й обговорення. На кафедрі медицини катастроф, військової медицини, анестезіології та інтенсивної терапії ЗДМУ впроваджені такі форми СН:

1. Командні заняття. Ця форма СН використовується нами при роботі з групою студентів під час модульних занять (рис. 1). Командні заняття виявилися дуже ефективними під час відпрацювання алгоритму серцево-легеневої реанімації (СЛР), надання екстреної медичної допомоги (ЕМД) при травмі. Вони надають змогу відпрацювати в команді (групі) такі моменти, як:

- практичні навички роботи в команді (елемент змагання);

- розподіл обов’язків серед членів “команди” під час надання ЕМД;

- взаєморозуміння серед членів “команди” під час надання ЕМД;

- питання у спроможності бути лідером у критичній ситуації.

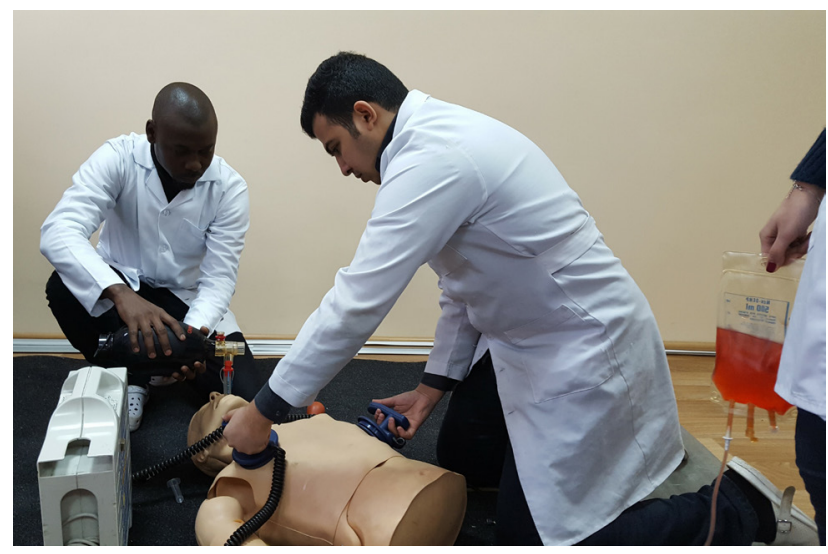

Рис. 1. Відпрацювання алгоритму СЛР під час навчального процесу.

2. Майстер-класи. Ця найпоширеніша форма $\mathrm{CH}$ використовувалась нами під час проведення науково-практичних конференцій (рис. 2). Проведення майстер-класів складається 3 таких етапів навчання, як:

1) визначення рівня володіння клінічними навичками на початку заняття;
2) індивідуальне виконання практичних навиків на муляжах, демонстрація;

3) перевірка викладачем рівня опанування практичних навиків;

4) дебрифінг (детальний аналіз роботи групи згідно з єдиним алгоритмом дій).

Ця форма СН є дуже ефективною під час відпрацювання практичних навичок надання ЕМД постраждалим з різними видами травм, тимчасової зупинки зовнішньої кровотечі, використання внутрішньокісткового доступу, забезпечення прохідності дихальних шляхів.

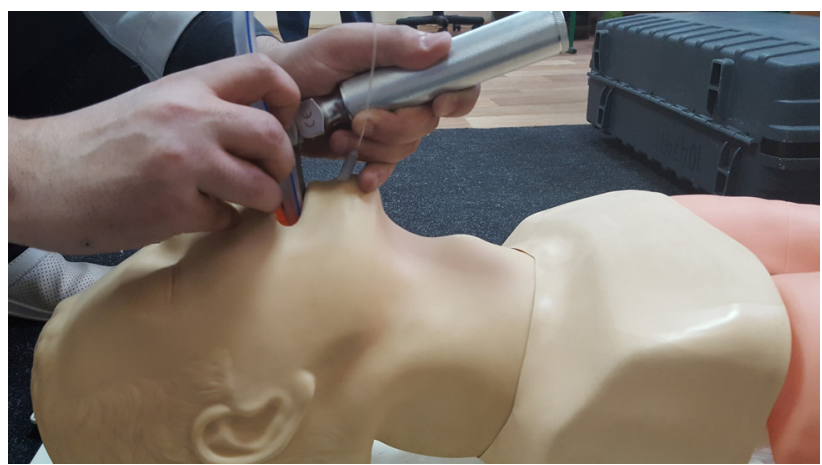

Рис. 2. Опанування практичного навику інтубації трахеї.

3. Семінари-тренінги. Тема семінару-тренінгу визначається як окремий модуль у загальній програмі підготовки фахівців. Змістові модулі відповідають питанням, що розглядаються в процесі проведення семінару за різними формами та методами навчання. Визначення цільової групи передбачає забезпечення відповідності змісту семінару реальним умовам праці учасників навчального процесу. Проведення 1-2-денних семінарів-тренінгів було дуже показовим і ефективним під час роботи з військовослужбовцями, волонтерами, школярами. Іноді теми одного семінару-тренінгу можуть поєднуватися. Наприклад: проведення семінару для школярів багатопрофільного ліцею з надання домедичної допомоги англійською мовою зі студентами шостого курсу міжнародного факультету ЗДМУ (рис. 3).

4. Змагання. Ця форма СН використовується нами з 2015 року, коли вперше у м. Запоріжжі був проведений Запорізький обласний чемпіонат бригад Е(Ш)МД. Студенти мають змогу взяти участь у змаганнях у ролі статистів, помічників суддів, учасників. Так, вже в 2016 році команда студентів ЗДМУ зайняла перше місце в обласному чемпіонаті бригад Е(Ш)МД, який складався з конкурсних завдань з проведення СЛР, надання ЕМД при політравмі, нефатальному втопленні, проведення медичного сортування (рис. 4). 


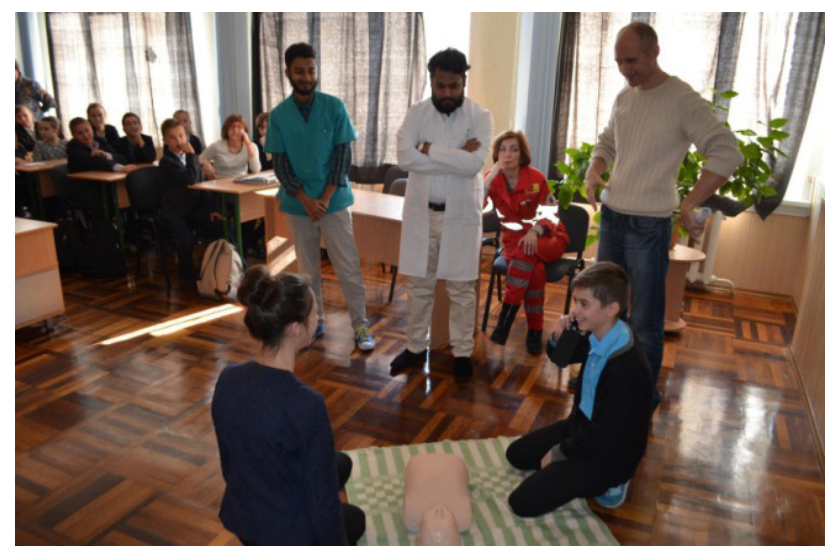

Рис. 3. Волонтерське заняття зі школярами.

Висновки. 1. Форми симуляційного навчання (командні заняття, майстер-класи, семінари-тренінги, змагання) є високоефективною системою практичної підготовки студентів медичних вузів.

2. Командні заняття $є$ пріоритетною формою відпрацювання алгоритму серцево-легеневої реанімації, надання екстреної медичної допомоги при травмі.

3. Майстер-класи слід використовувати як елемент практичної підготовки під час проведення науково-практичних конференцій.

\section{Список літератури}

1. Аналіз навчання бригад екстреної (швидкої) медичної допомоги проведенню серцево-легеневої реанімації 3 використанням симуляційних технологій / О. А. Льовкін, К. В. Серіков, С. Ю. Конаков [та ін.] // Екстрена медицина: від науки до практики. - 2014. - № 5-6. - С. 44-50.

2. Принципы подготовки врачей-интернов разных специальностей по циклу “Неотложные состояния” / В. В. Ехалов, В. И. Слива, Д. М. Станин [и др.] // Медицина неотложных состояний. - 2011. - № 4. C. $124-129$.

\section{References}

1. Liovkin, O.A., Serikov, K.V., Konakov, S.Yu., \& Malashenko, K.K. (2014). Analiz navchannia bryhad ekstrenoi (shvydkoi) medychnoi dopomohy provedenniu sertsevo-lehenevoi reanimatsii z vykorystanniam symuliatsiinykh tekhnolohii [Analysis training for emergency medical services crews of cardio-pulmonary resuscitation using simulation technology]. Ekstrena medytsyna: vid nauky do praktyky-Emergency Medicine: from Research to Practice, 5-6, 44-50 [in Ukrainian].

2. Yekhalov, V.V., Sliva, V.I., Stanin, D.M., LyashchenkoO.V., \& Kligunenko, Ye.N. (2011). Printsipy podgotovki vracheyinternov raznykh spetsialnostey po tsiklu "Neotlozhnye sostoyaniya” [Basis of training of interns of different specialty on a training cycle "Emergency conditions"]. Meditsina

Електронна адреса для листування: levkin03@rambler.ru

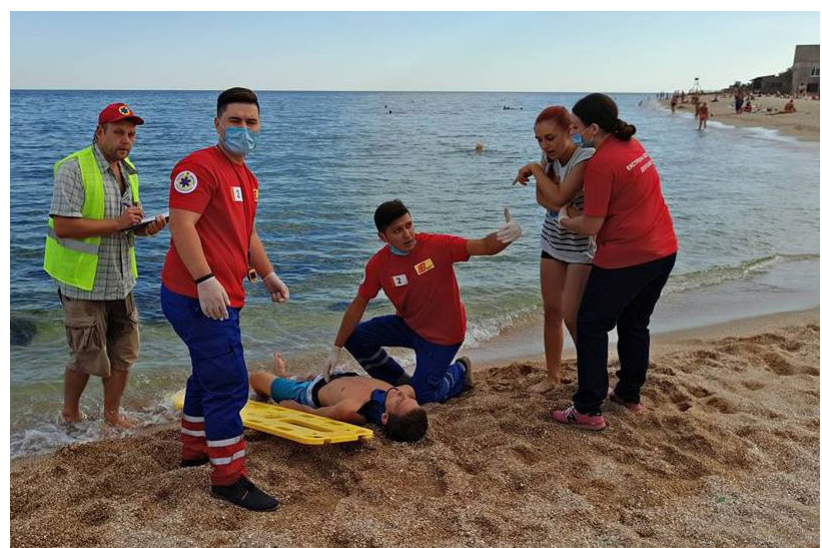

Рис. 4. Запорізький обласний чемпіонат бригад Е(Ш)МД.

4. Семінари-тренінги є оптимальною формою навчання у роботі з немедичною аудиторією (військовослужбовцями, волонтерами, школярами).

5. Змагання допомагають студентам вдосконалити практичні навички, оволодіти навичками первинного медичного сортування тощо.

Перспективи подальших досліджень. У перспективі ми плануємо опанувати нові форми симуляційного навчання та впровадити їх у навчальні модулі для студентів Запорізького державного медичного університету.

3. Льовкін О. А. Симуляційні форми навчання бригад Е(Ш)МД / О. А. Льовкін, Б. М. Голдовський, К. В. Серіков // Медицина неотложных состояний. -2014.№ 62. - С. 121-124.

4. Марков Ю. І. Симуляційні технології відпрацювання практичних навиків серцево-легеневої реанімації в медицині невідкладних станів / Ю. І. Марков, В. В. Орел // Медицина неотложных состояний. - 2014. - № 7 (62). C. $157-158$.

neotlozhnykh sostoyaniy - Emergency Medicine, 4, 124129 [in Russian].

3. Liovkin, O.A., Holdovskyi, B.M., \& Serikov, K.V. (2014). Symuliatsiini formy navchannia bryhad E(Sh)MD [Simulation training of emergency medical services crews]. Meditsina neotlozhnykh sostoyaniy - Emergency Medicine, 62, 121-124 [in Ukrainian].

4. Markov, Yu.I., \& Orel, V.V. (2014). Symuliatsiini tekhnolohii vidpratsiuvannia praktychnykh navykiv sertsevolehenevoi reanimatsii v medytsyni nevidkladnykh staniv [Simulation technology of cardio-pulmonary resuscitation training in emergency care medicine]. Meditsina neotlozhnykh sostoyaniy - Emergency Medicine, 7, 62, 157-158 [in Ukrainian]. 